\title{
MODELLING LONG TERM FOREST FIRE RISK USING FIRE WEATHER INDEX UNDER CLIMATE CHANGE IN TURKEY
}

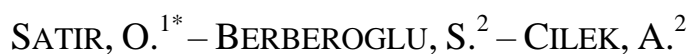 \\ ${ }^{1}$ Department of Landscape Architecture, Yuzuncu Yil University, 65080, Van, Turkey \\ ${ }^{2}$ Department of Landscape Architecture, Cukurova University, 01330, Adana, Turkey \\ *Corresponding author \\ e-mail:osatir@yyu.edu.tr
}

(Received $20^{\text {th }}$ Jul 2016; accepted $12^{\text {th }}$ Sep 2016)

\begin{abstract}
Fire weather indices (FWIs) are among the most effective techniques to define real time or long term forest fire risk using meteorological data. In this research, long term forest fire risk of Turkey was modelled using a fire weather index called F index for present $(1990-2010)$ and future $(2061-2080)$ periods. Dry bulb temperature, relative humidity and maximum wind speed were mapped using 945 meteorological stations in Turkey, with a spatial resolution of $250 \mathrm{~m}$. Long term mean F index values (from 1990 to 2010 and from 2061 to 2080) were calculated for 7 months representing fire seasons from April to October. Average fire occurrence of each month and monthly mean $\mathrm{F}$ index values of the forestlands were correlated using Pearson correlation statistic and determination coefficiency $\left(\mathrm{R}^{2}\right)$ was 0.82. Additionally, projected annual mean temperature and humidity based on HadGEM2-ES model RCP 4.5 scenario were used to derive future F index. Mean F index values of the forestlands were shown that forest fire risk of Turkey will have an increase of $21.1 \%$ in 2070s.
\end{abstract}

Keywords: future forest fire risk, Turkey, geostatistical mapping and modelling, fire weather condition.

\section{Introduction}

Forest fire risk assessment provides useful information for forest fire managers to plan and allocate firefighting resources, and has been used widely by forest agencies (Schneider et al., 2008). Forest fire risk assessment, based on an integrated index, becomes an important tool for forest fires management. The integrated index includes the information about fuel, topography and weather condition which constitute potential fire environment together (Liu et al., 2009).

Fire weather is traditionally represented by five main meteorological variables: temperature, relative humidity, wind speed and direction, and precipitation. Different types of data can be used depending on the particular functional form of the different fire danger indices, however usually they are derived from these five main meteorological variables (Hasson et al., 2008). There are many fire weather indices; however, three of them are outshined in literature: i) Canadian Forest Fire Danger Rating System (FFDRS) (Stocks et al., 1989), ii) National Fire Danger Rating System in US (NFDRS) (Deeming et al., 1977) and, iii) Forest Fire Danger Index (FFDI) (McArthur, 1967). FFDRS has been used since 1971 in Canada, and adopted to some other countries such as Portugal (Viegas et al., 1999), South-Eastern Asia (de Groot et al., 2005) and New Zealand (Dudfield, 2004). NFDRS has been used by different agencies since 1972 and FFDRS has been widely used in South Australia since 1967.

Forest Fire Weather Indices (FFWIs) are described fire occurrence environment based on climate variables. In a forest ecosystem, high temperature and low humidity indicate high fire probability. Additionally, wind speed has strong influence on fire 
probability and spread as a result of drying and directing effects. There are many forest fire risk evaluation methods including, remote sensing based methods, FFWIs (Gabban et al., 2008; Maffei et al., 2007) and integrated data methods in geographical information system (GIS) interface such as multi criteria evolution or artificial neural network (Dickson et al., 2006; Satir et al., 2016). Even if integrated methods are more accurate, FFWIs have two significant advantages over other approaches; i) Applicants are not required any extra computing knowledge and additional dataset so FFWIs application is more user friendly than other approaches. ii) FFWIs capable of predicting present, past and future fire risk by introducing relevant climate dataset. Addionally, a strong correlation was observed between burnt area and weather condution in a part of Aegean region of Turkey, which is at high forest fire risk, by Ertugrul and Varol, (2016).

Forest ecosystem activities, forest fires, land degradations, soil erosion and human pressure on forest areas will likely be increased according to climate change projections (Liu et al., 2013; Cilek et al., 2015; Fan et al., 2016). It was declared in COP 21 UN Climate Change Conference organized in Paris on November 2015 that mean temperature raise will not exceed $2{ }^{\circ} \mathrm{C}$ in the world until 2100. Summer temperature raise of Turkey will be in between $2-3{ }^{\circ} \mathrm{C}$ according to the $5^{\text {th }}$ IPCC report and HadGEM-ES projection with RPC 4.5 scenario (Demir et al., 2013). This scenario was selected in this study because RPC 4.5 is not too pesimistic or optimistic scenario. The purpose of this study was to predict present and future forest fire risk of Turkey based on climate variables using fire weather index called F index described by Sharples et al. (2009a). The results will support the forest fire prevention plans for future actions. Additionally, forest fire fighting strategies can be modified with respect to future predictions and integrating with new technologies like real time satellite monitoring systems and unmanned air vehicles (UAVs).

\section{Study area}

Turkey covers an area of $783.562 \mathrm{~km}^{2}$ and population is 78.74 million (TSI 2016). Approximately $20-25 \%$ of Turkey is covered by productive forestland. Turkey includes three main flora regions called Mediterranean (southern and eastern part), Euro-Siberian (northern part) and Iran - Turan (middle and eastern part). Approximately 9000 plant species exist in Turkey and 3000 of them are endemic (Davis, 1965). Conifer forestlands are located mainly around Mediterranean and Aegean coastal places. However, black sea coastal regions are covered by largely deciduous forestlands. Pinus brutia Tenore, Pinus nigra J.F.Arnold, Pinus sylvestris L., Cedrus libani A. Rich and C. deodora G. Don, Abies cilicica Carr, A. nordmanniana Steven and A. Bornmulleriana Mattf. are the natural dominant conifers and Quercus pubescens Willd, Q. cerris L., Q. robur L., Q. Petraea Liebl, Fagus orientalis Lipsky., Carpinus orientalis Mill, C. betulus L.., Platanus orientalis L., Acer negundo L., Fraxinus ornus L. and Alnus glutinosa L., A. orientalis Decne are the most common deciduous forest trees in Turkey. This richness is the function of topographic and seasonal climate variation together with historical human activities and Turkey has been geographically a bridge between Asia and Europe (Fig. 1). 


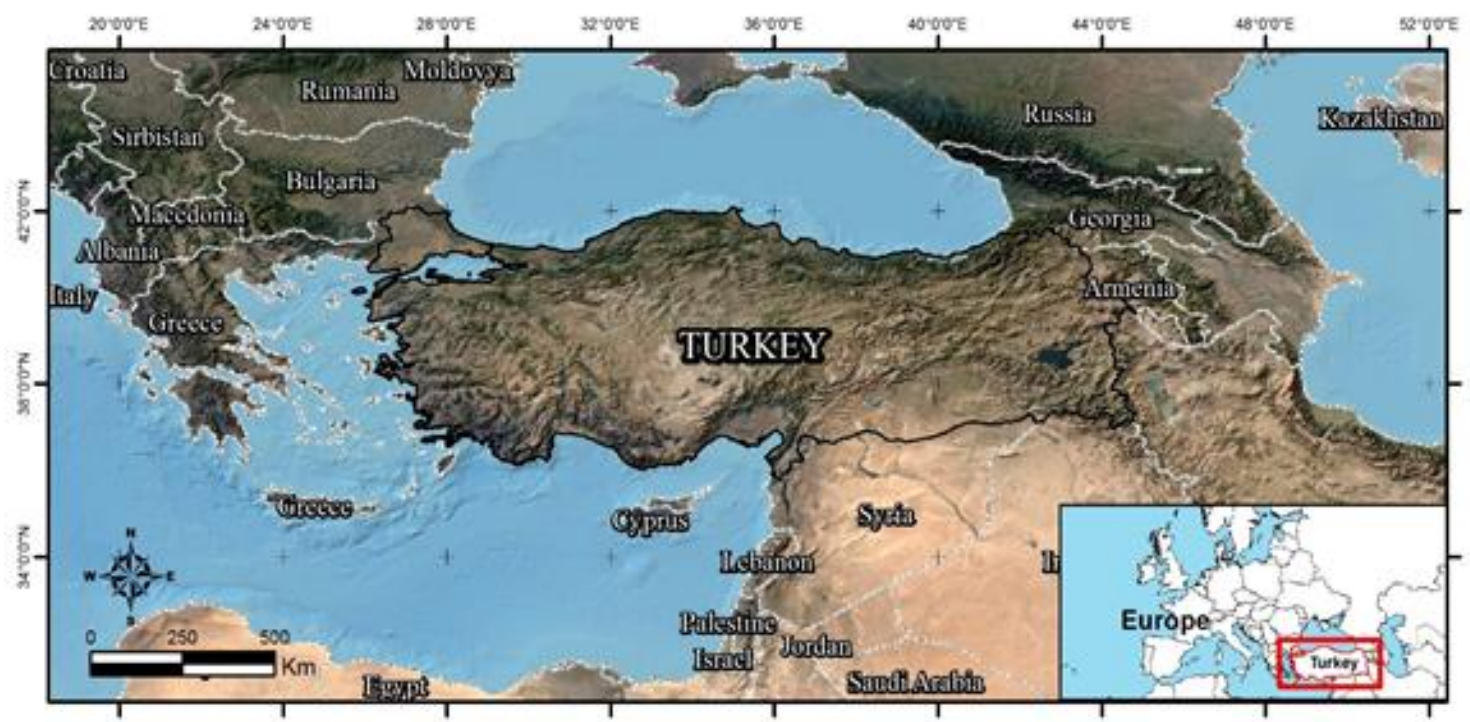

Figure 1. Location of the study area (Turkey)

\section{Forest fires in Turkey}

Forest fires are one of the most significant forest degradation factor in Turkey. Particularly, forestlands located in Mediterranean (south part) and Aegean (west part) (arid and semi-arid) regions of Turkey are under an intense risk during fire season (from April to October) (Ozturk et al., 2010). Unfortunately, Turkey always keeps its place in top 5 or 6 in Mediterranean Basin Countries on forest fire (Table 1) and 11.456 ha forest area burnt only in 2013 (JRC, 2014).

Table 1. Top 6 countries on forest fires and forest area lost in 2013 in European Region (JRC 2014)

\begin{tabular}{lrrrrrr}
\hline Country & Portugal & Spain & Greece & Italy & Algeria & Turkey \\
\hline No. of fires & 19291 & 10626 & 862 & 2936 & 2443 & 3755 \\
$\begin{array}{l}\text { Burned area } \\
\text { (ha) }\end{array}$ & 152756 & 58985 & 46676 & 20076 & 13396 & 11456 \\
\hline
\end{tabular}

90390 ha forest area was damaged by fires between 2004 and 2013 in Turkey (TEMA, 2014). Although the forestlands with highest density are located in north part of Turkey, forest fire occurrence is higher in the western and southern parts. Because, climatic factors affect the forest fire diversities. Black sea region (north part) of Turkey is the most humid region and annual mean precipitation varies in between 1500 and $2200 \mathrm{~mm}$ based on elevation (TMSS, 2015). However, west and south regions are very hot in summer season and annual mean precipitation is ranging in between 400 and $800 \mathrm{~mm}$.

\section{Material and Methods}

\section{Dataset}

Long term climate dataset for present and future, forest mask of Turkey and long term seasonal forest fire records of Turkey were used in this study (Table 2). 
Table 2. Detailed dataset specifications

\begin{tabular}{llll}
\hline Data & Deriving method & Purpose & Source \\
\hline $\begin{array}{l}\text { Current climate data } \\
(1990-2010)\end{array}$ & $\begin{array}{l}\text { Interpolation by } \\
\text { ANUSPLIN }\end{array}$ & $\begin{array}{l}\text { Current F index } \\
\text { calculation }\end{array}$ & $\begin{array}{l}\text { Government } \\
\text { meteorological } \\
\text { stations }\end{array}$ \\
$\begin{array}{l}\text { Future Climate Data } \\
(2061-2080)\end{array}$ & $\begin{array}{l}\text { WorldClim climate } \\
\text { database interpolated by } \\
\text { ANUSPLIN using } \\
\text { HadGEM2-ES model }\end{array}$ & $\begin{array}{l}\text { Future F index } \\
\text { calculation }\end{array}$ & Hijmans et al. 2005. \\
& $\begin{array}{l}\text { RCP 45 scenario } \\
\text { Regression tree method }\end{array}$ & $\begin{array}{l}\text { Extraction of the forest } \\
\text { areas }\end{array}$ & $\begin{array}{l}\text { Berberoglu \& } \\
\text { Forest mask of }\end{array}$ \\
\begin{tabular}{l} 
Turkey \\
\hline
\end{tabular}
\end{tabular}

Present climate dataset was extracted from 945 government meteorological stations of Turkey for the period 1990 - 2010. Seasonal mean dry bulb temperature, mean relative humidity and annual maximum wind speed data were obtained for present time. This dataset was interpolated using ANUSPLIN software package with $250 \mathrm{~m}$ spatial resolution considering climate station locations and elevation (Fig. 2).

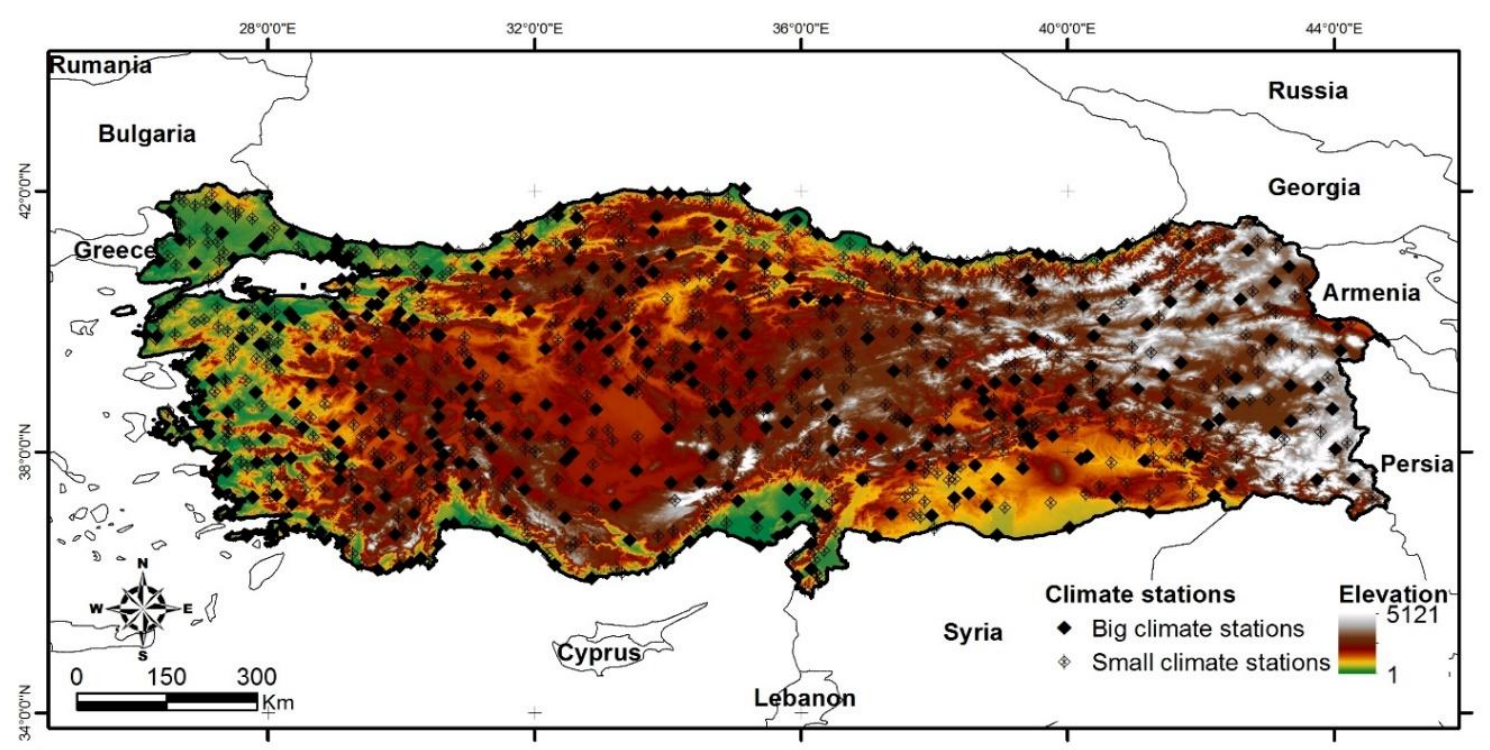

Figure 2. Location of climate stations on Digital Elevation Model of Turkey

Future climate data was derived from WorldClim Global Climate Data platform (WGCD, 2015). This platform provided free global climate data for past-current and future time. WorldClim is a set of global climate layers (climate grids) with a spatial resolution of $1 \mathrm{~km}^{2}$. The data can be used for mapping and spatial modelling in a GIS or with other computer programs. In this extent, Hijmans et al. (2005) were created global climate dataset using ANUSPLIN software package in several spatial resolutions. Future climate data was projected from global climate models (GCMs) for four representative concentration pathways (RCPs) which was introduced in the Fifth Assessment IPCC report. The GCM output was downscaled and calibrated (bias 
corrected) using WorldClim as baseline 'current' climate data (Hijmans et al., 2005). HadGEM2-ES model RCP 4.5 scenario was used to derive future climate dataset. Future mean temperature was derived and future relative humidity was predicted using regression equation derived using temperature, elevation and humidity. Current wind speed data was used for the future analysis. Because, wind projections in WorldClim database for future were different in terms of resolution, scenario, climate stations etc. So this research considered only future temperature and relative air humidity. Future wind speed is neglected. Additionally, wind speed modelling for the long term future period has still uncertainties, particularly, maximum wind speed (Rockel and Woth, 2007). Nukulin et al. (2010) showed that projected future wind speed of Turkey using 6 different global climate models under the SRES A1B scenarios were stabile relative to other European countries.

Current forest mask of Turkey was integrated from Berberoglu and Hickler (2014) percent tree cover map of Turkey. This map was produced using MODIS multitemporal dataset and Geoeye images with 12\% RMSE in 2010. This map was enabled applying a threshold value (10\% cover) to define current forestlands in Turkey.

Seasonal long term forest fire records were obtained from Ministry of Forestry and Water Affairs of Turkey from 2005 to 2011 period. Monthly forest fire counts and monthly calculated mean $\mathrm{F}$ index values were compared each other to test the seasonal sensitivity of the F index to forest fire occurrence.

\section{Methodology}

There are three main steps in the study; i) Interpolating the current climate data using ANUSPLIN, ii) Downscaling future climate data and deriving future humidity by regression, iii) $\mathrm{F}$ index calculation and change comparison (Fig. 3).

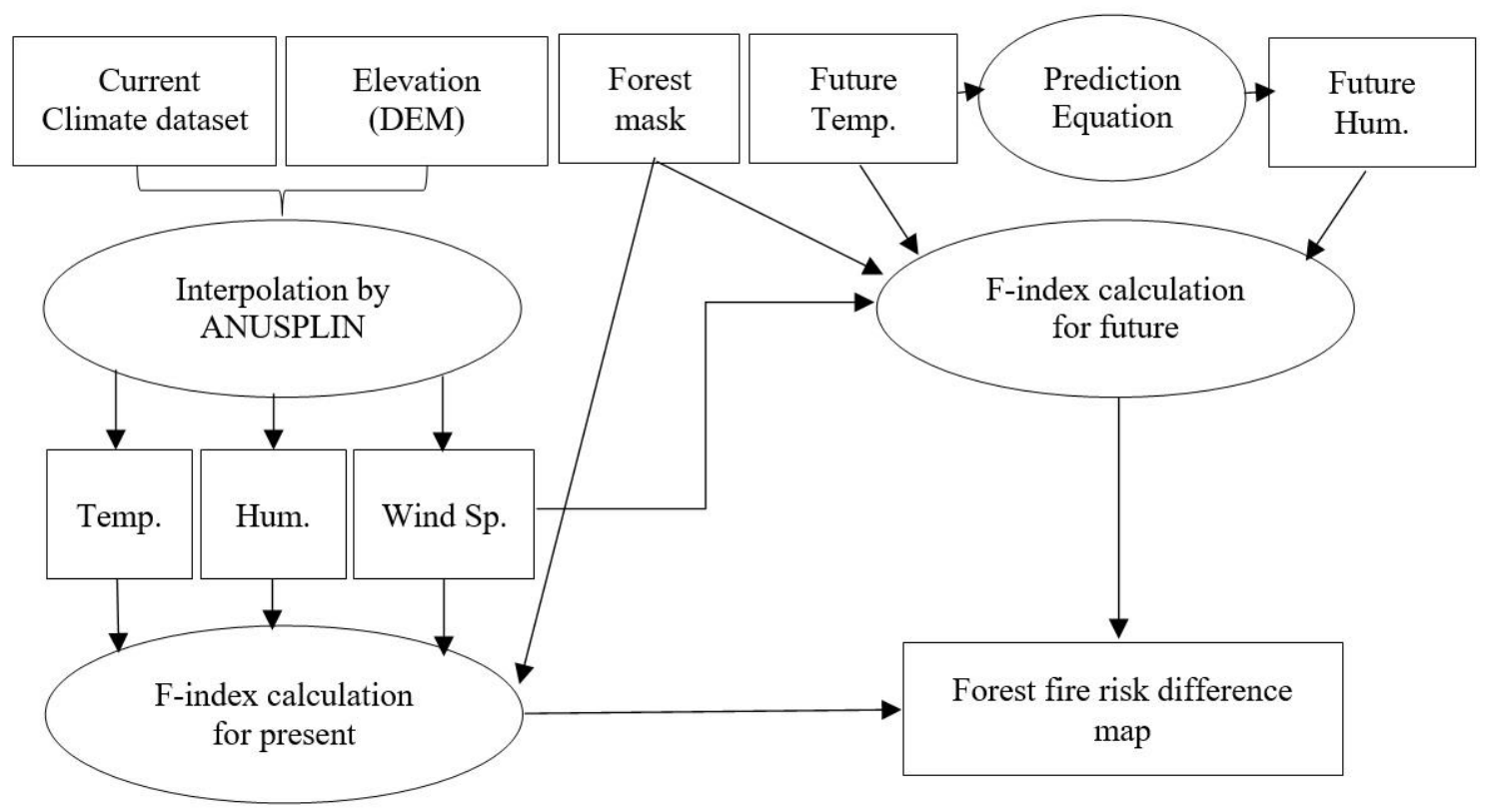

Figure 3. Summary of the methodology 


\section{Climate data interpolation}

ANUSPLIN a statistical package developed by Dr. MF Hutchinson from The Australian National University, was used to interpolate climate data. This approach uses thin plate smoothing splines to create continuous surfaces from point data. The package is a popular interpolator which is often used for climate research and for the production of commercial climate maps (Jeffrey et al., 2001; Johnson et al., 1999). ANUSPLIN 4.3 software package was used in this study (Hutchinson, 2004) that implements the thinplate smoothing splines procedure described by Hutchinson (1995). It was used in global studies successfully (New et al., 1999), performed more accurately in comparison to multiple interpolation techniques (Jarvis and Stuart, 2001).

\section{Future climate data}

Future temperature data was derived from WorldClim database, and relative humidity data was produced using linear relationship between temperature and relative humidity. In this extent, current long term mean temperature, elevation and relative humidity data $(1990$ - 2010) were used as descriptive variables to create regression equation to predict humidity data. Present wind speed data was used in calculation process of future $\mathrm{F}$ index. The reason of this was discussed earlier in data characteristics section.

Spatial resolution of future climate dataset was $1 \mathrm{~km}$ however, current climate data was mapped in $250 \mathrm{~m}$. A simple downscaling technique was applied to make compatible both dataset spatially. Current temperature map rescaled to $1 \mathrm{x} 1 \mathrm{~km}$ and percent difference was obtained for each grid. Calculated difference was applied in GIS environment to current $250 \mathrm{~m}$ data and future temperature data was produced in same spatial resolution.

\section{F index calculation}

F index introduced by Sharples et al. (2009a) is a combination of information on wind speed and fuel moisture content, where the latter is derived through consideration of temperature and relative humidity. Intuitively, fire danger decreases as fuel moisture content increases, whereas increases as wind speed increases. Sharples et al. (2009a) compared three widely used fire weather index (FWI) in the literature and produced a simple FWI which has advantages over others called F index. Additionally, Sharples et al. (2009b) introduced a dimensionless fuel moisture index (FMI), compared with several existing models for determining the moisture content of fine, dead fuels. The results suggested that FMI provides a measure of fuel moisture content that is equivalent to that produced by the complex models. The FMI is given by the simple expression:

$$
\mathrm{FMI}=10-0.25(\mathrm{~T}-\mathrm{H})
$$

Where $T$ is the dry bulb temperature $\left({ }^{\circ} \mathrm{C}\right)$ and $H$ is the relative humidity $(\%)$. F index calculated by the following equation:

$$
\mathrm{F}=\max (\mathrm{U}) / \mathrm{FMI}
$$

$U$ is the wind speed $\left(\mathrm{km} \mathrm{h}^{-1}\right)$ and FMI fuel moisture index defined in Equation (1). 


\section{Results}

Study results were presented in three stages: i) Interpolation results of the present $(1990$ - 2010) $\mathrm{F}$ index derived from climate data, ii) calculating future $\mathrm{F}$ index and, iii) evaluating the forest fire risk rate between two periods under the climate change.

\section{Mapping present climate data and future humidity}

Procedure developed by Hijmans et al. (2005) was used to map the current climate data using ANUSPLIN-SPLINA package. ANUSPLIN-SPLINA uses each station as a data point, whereas SPLINB uses a subset of stations. Second-order spline was fitted using latitude, longitude, and elevation as descriptive variables as it resulted the lowest overall cross-validation errors comparison to other settings (e.g. third-order spline, elevation as a covariate). Long term mean temperature, relative humidity and wind speed data were interpolated with a spatial resolution of $250 \mathrm{~m}$ using 945 climate stations together with SRTM DEM data of Turkey. All interpolated data characteristics and RMSE were shown in Table 3.

Table 3. Interpolation validity and data characteristics

\begin{tabular}{lrrrr}
\hline Climate data & Minimum value & Maximum value & Mean value & RMSE \\
\hline Mean temperature $\left(\mathrm{C}^{\mathrm{o}}\right)$ & -1.32 & 26.4 & 16.3 & 1.08 \\
Mean relative humidity & 32.7 & 79.2 & 58.7 & 5.3 \\
$(\%)$ & & & & \\
Wind speed $(\mathrm{km} / \mathrm{h})$ & 1.53 & 3.34 & 2.15 & 0.4 \\
\hline
\end{tabular}

Long term (1990 - 2010) mean temperature, humidity and wind speed maps of forestlands were extracted using forest mask that was created from present (2010) percent tree cover map of Turkey. Firstly these maps were obtained monthly for forest fire season (Fig. 4) and monthly mean values were used in analyses (Fig. 5).

Future temperature data was derived from WorldClim dataset in $1 \mathrm{~km}$ spatial resolution and it was downscaled to $250 \mathrm{~m}$ spatial resolution. Future long term mean humidity data was estimated using multiple regression of present temperature, elevation and humidity. Relationship of these maps and long term humidity map were analysed through determination co-efficiency $\left(\mathrm{R}^{2}\right)$ and prediction equation (Table 4).

Table 4. MLR model equation for future humidity calculation

\begin{tabular}{lllll}
\hline $\begin{array}{l}\text { Dependent } \\
\text { Variable }\end{array}$ & Independent Variables & $\begin{array}{l}\text { Prediction Model } \\
\text { Equation }\end{array}$ & $\mathrm{R}$ & $\mathrm{R}_{\text {adj }}^{2}$ \\
\hline $\begin{array}{l}\text { Long term mean } \\
\text { humidity }\end{array}$ & $\begin{array}{l}\text { Long term mean } \\
\text { temperature and DEM }\end{array}$ & $\begin{array}{l}\mathrm{H}=129.1-3.19 \mathrm{~T}- \\
0.018 \mathrm{DEM}\end{array}$ & 0.883 & 0.781 \\
\hline
\end{tabular}

"H" refers to humidity, "T" refers to temperature 


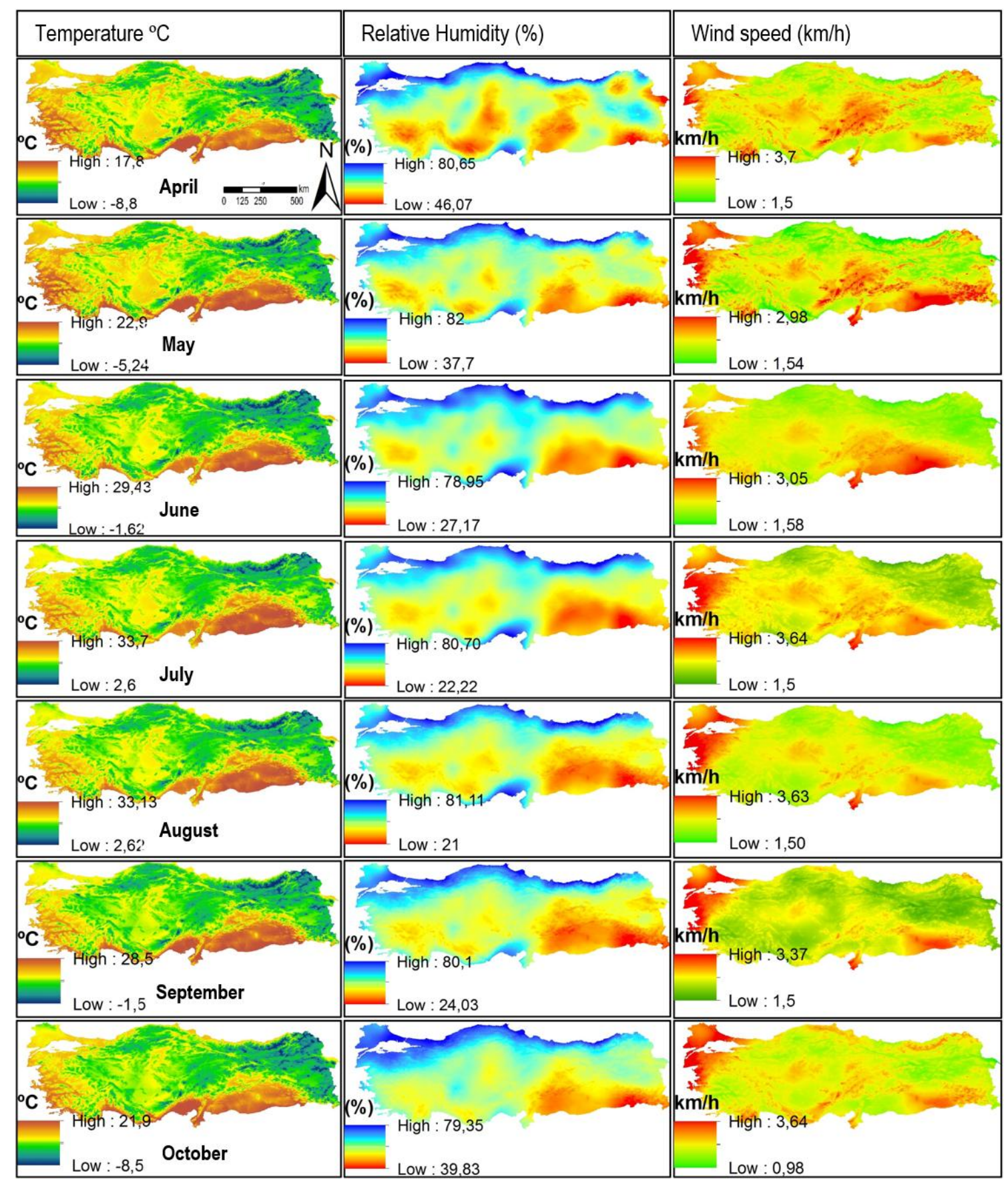

Figure 4. Interpolated monthly mean climate dataset for $F$ index calculation

Mean temperature difference between the two periods was detected as $3.61{ }^{\circ} \mathrm{C}$. The highest temperature rise was estimated at the Eastern Mediterranean part and Eastern Black Sea Region of Turkey. On the other hand mean relative humidity decreased in the same regions, while a large increase will take place at the western part of Turkey according to HadGEM2-ES model RCP 4.5 scenario (Fig. 6 ). 


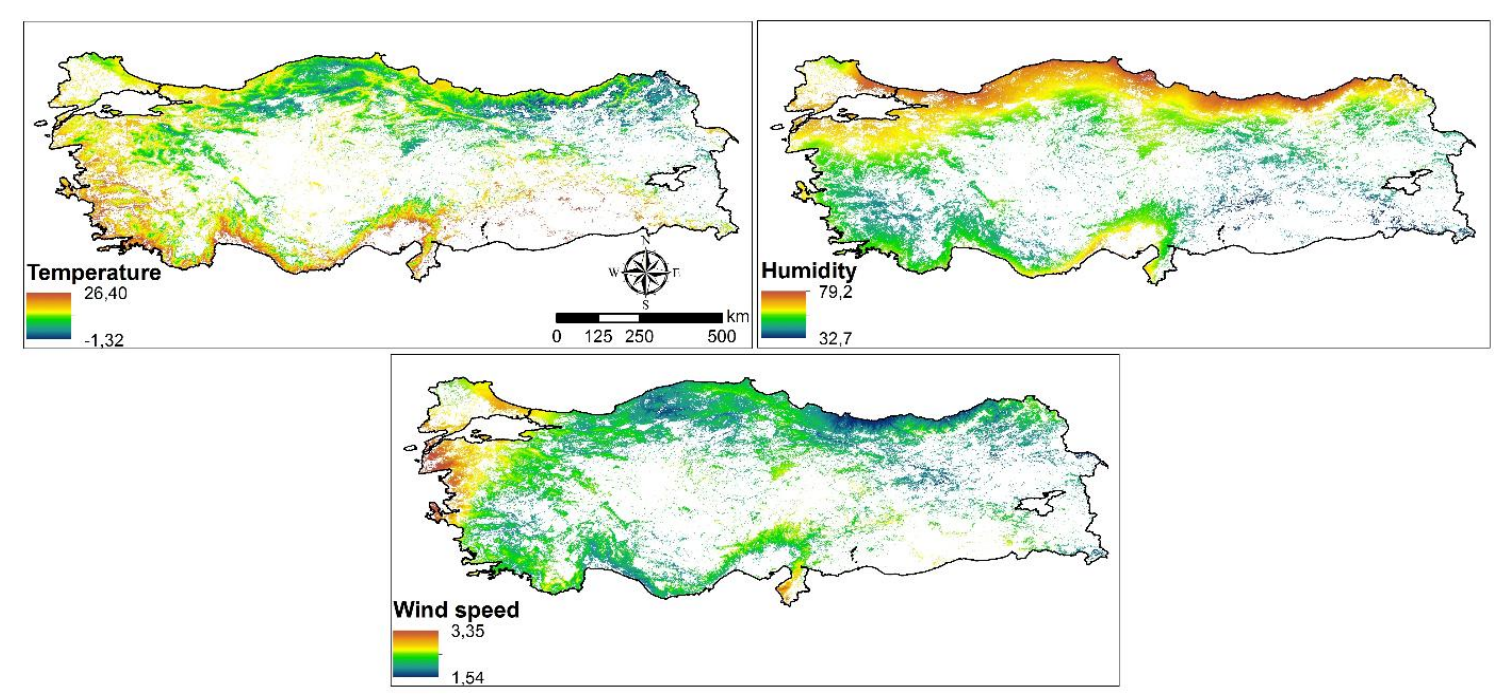

Figure 5. Long term mean temperature $\left({ }^{\circ} \mathrm{C}\right)$, relative humidity $(\%)$ and wind speed $\left(\mathrm{km} \mathrm{h}^{-1}\right)$ maps of the current time period in forest areas

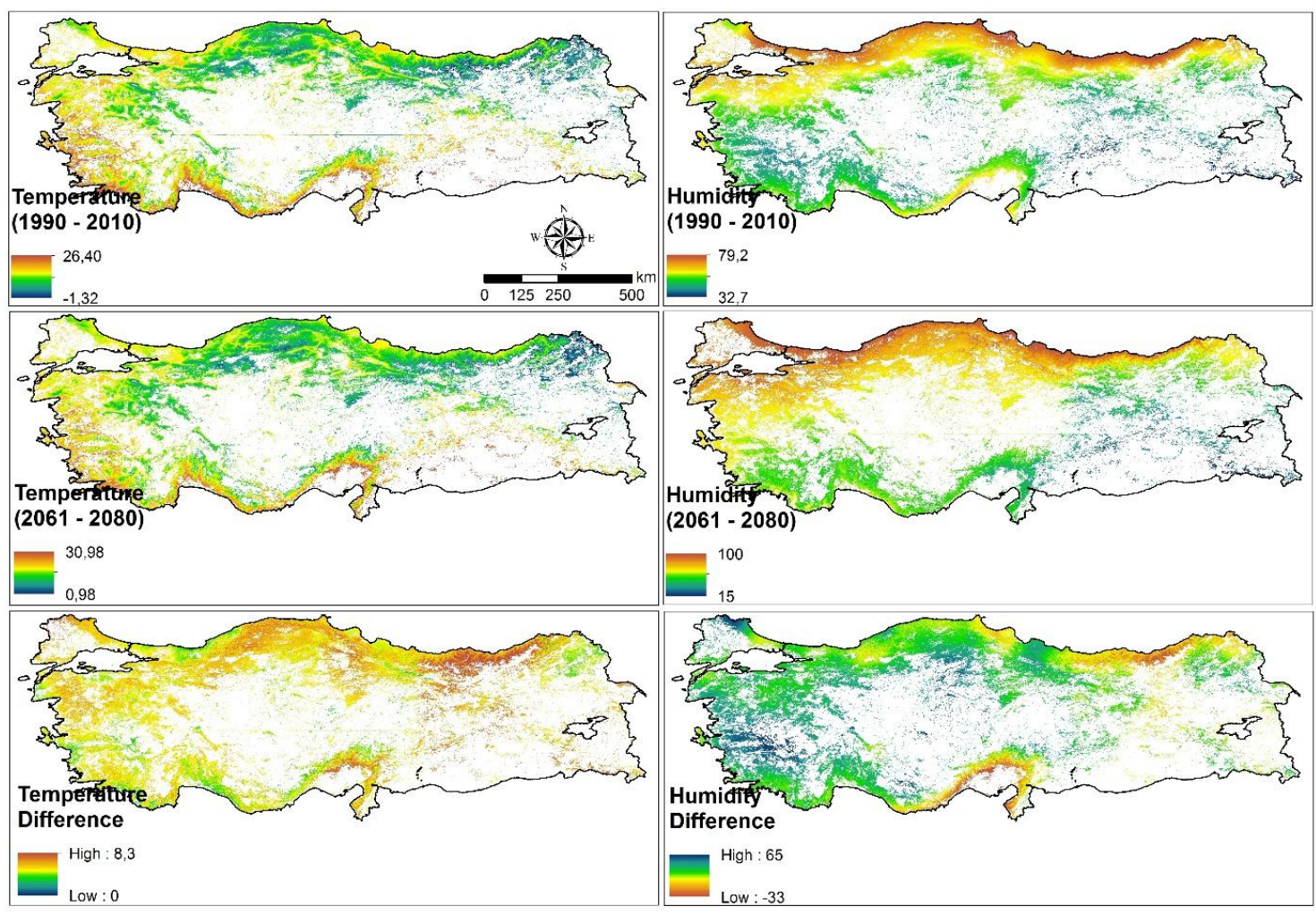

Figure 6. Long term temperature $\left({ }^{\circ} \mathrm{C}\right)$ and relative humidity (\%) difference (future-current)

\section{Forest fire rate change based on $F$ index}

Firstly, F index was validated using monthly forest fire counts between 2005 and 2011, and mean F index values of Turkey in fire season (April-October). With that, calculated $F$ index sensitivity vs. forest fires were evaluated. In this extent, determination co-efficiency $\left(\mathrm{R}^{2}\right)$ was derived as 0.82 , and a significant linear 
relationship was detected in a positive way (Fig. 7). This result showed that $\mathrm{F}$ index and forest fire occurrence or risk highly correlated with each other and it can be used as a forest fire risk rate indicator.

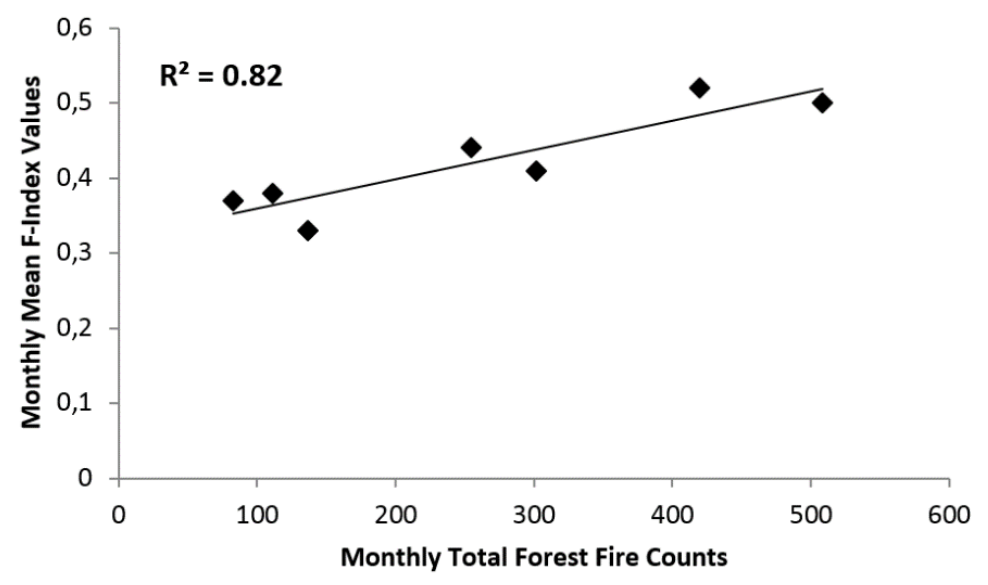

Figure 7. F index vs. forest fire occurrence

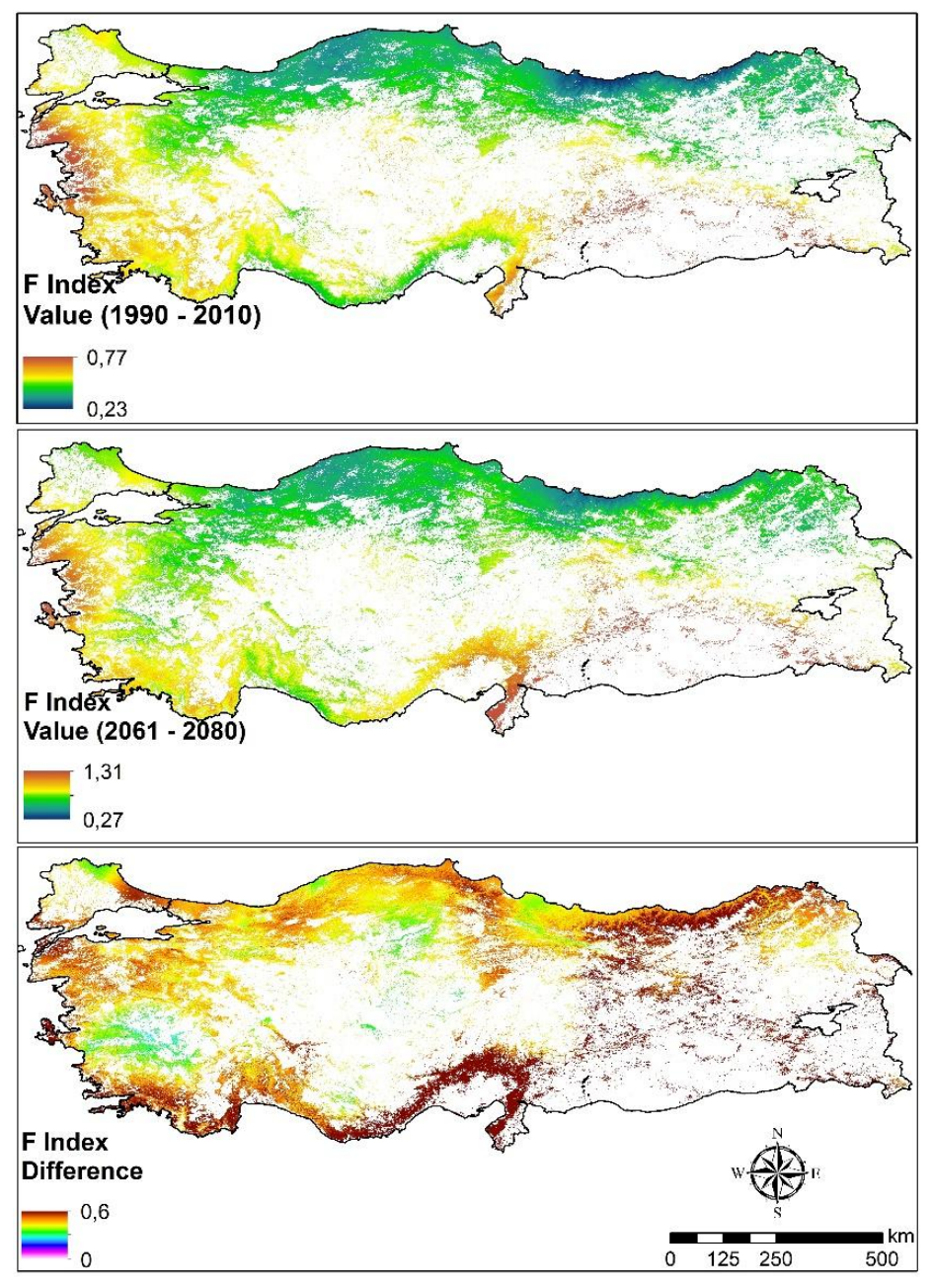

Figure 8. Current and future F index values and difference map of Turkey 
F index values were calculated for current and future time periods. Results showed that current and future mean F index values of forestlands were 0.387 and 0.469 respectively in Turkey. Forest fire risk rate increased approximately $21 \%$ in overall. The largest change was observed particularly in Eastern Mediterranean, Eastern Black Sea, and western coastal region of Turkey (Fig. 8). Forestlands located in southern and eastern coastal regions of Turkey, have already been under high forest fire risk. Therefore, especially these regions will most likely be affected from climate change.

\section{Basin scale risk evaluation}

Forest fire risk rate for present and future time was evaluated in basin scale. Turkey has 26 naturally bounderied basins (Fig. 9). Mean F index value of the each basin was calculated in ArcGIS environment using zonal analyses toolbox for present and future time. Basin scale F index change and percent rise were obtained and shown in Appendix 1. According to the $\mathrm{F}$ index change, forest fire risk probability will have been increased in 2070s, particularly in Eartern Mediterranean Basins such as Seyhan, Ceyhan, Hayat and Eart Mediterranean. In addition to this, Tigris, Eart Black Sea and Lake Van basins were outshined from other basins on increased forest fire probability.

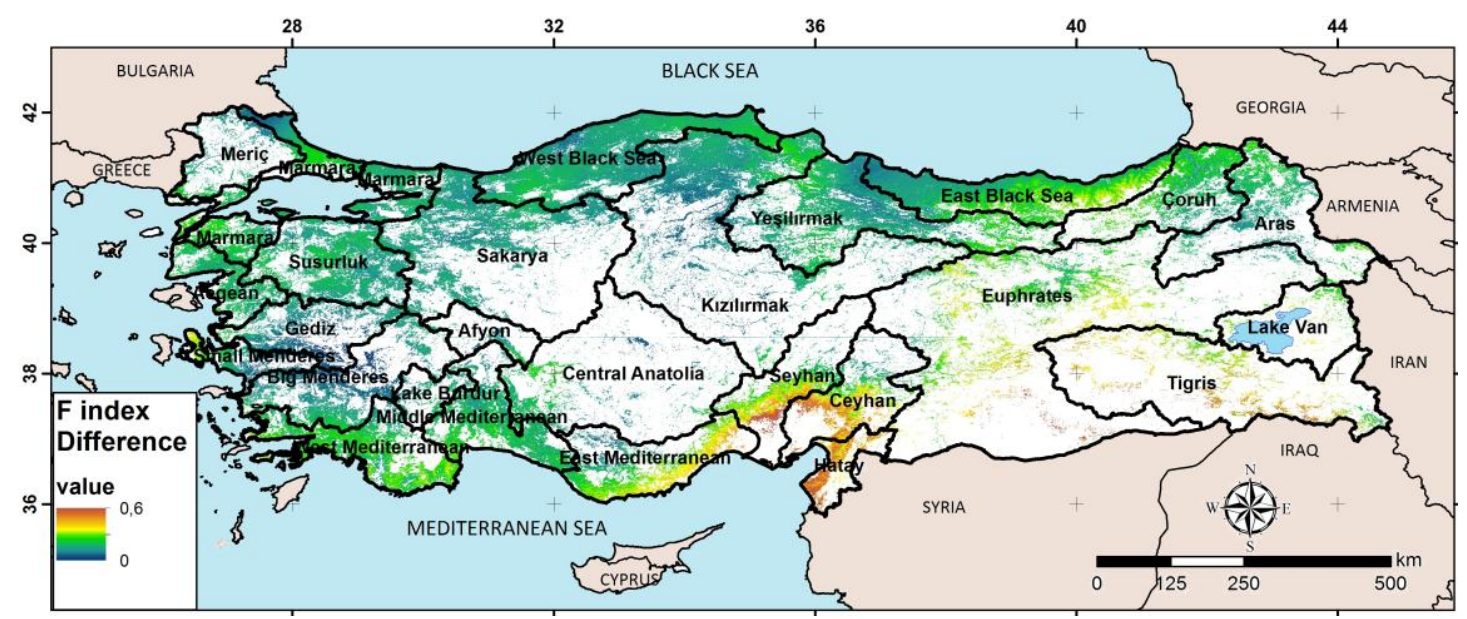

Figure 9. Basins of Turkey

\section{Discussion}

This study presented effects of climate change on forest fire risk rate using a fire weather index in Turkey. Forest fires are among the most important environmental risks in Turkey and other countries in the Mediterranean, Australia and America (Dios et al., 2007). Future predictions provide valuable information to develop planning strategies against forest fires. Forestlands located at low fire risk zones currently may have large risks in the future as a result of climate change. Thus, new strategies need to be developed such as establishing new firefighting stations, water pools or UAV stations. In this study, forest fire risk rates difference between present and future were mapped to evaluate potential risk areas. Particularly, Mediterranean part of Europe will be under high risk according to the future forest fire risk scenarios, and climate change which will affect fire seasons in a year (Moriondo et al., 2006). The results of this study supported this assumption for Turkey. Additionally, Eastern Black Sea Region of Turkey will also likely be under risk in the future. Forest fires are triggered by 
vegetation changes (forest cover, dominant plant species, land degradation), which is another variable for the forest fire in future landscapes (Allen et al., 2010; Breugel et al., 2016). F index was found to have a strong correlation with fire counts and it indicates that potential forest fire counts will rise in the future by $21.1 \%$ overall in Turkey. Additionally, when the fire risk rate increases, vegetation change is expected, particularly in the hot spots like Mediterranean coastal part of Turkey and Eastern Black Sea Region.

In conclusion, $\mathrm{F}$ index is an efficient forest fire risk assessment technique and it can be used for future forest fire risk assessment because it only requires climate data. Forest fire risk rate of Turkey will increase by around $21 \%$ in 2070 s according to HadGEM2-ES model RCP 4.5 scenario. New strategies are necessary for future to reduce forest fire effects on vegetation changes. Additionally, the issues of capacity building, new firefighting stations, equipment, and afforestation should be considered.

\section{REFERENCES}

[1] Allen, C.D., Macalady, A.K., Chenchouni, H., Bachelet, D., McDowell, N., Vennetier, M., Kizberger, T., Rigling, A., Breshears, D.D., Hogg, E.H., Gonzalez, P., Fensham, R., Zhang, Z., Castro, J., Demidova, N., Lim, J.H., Allard, G., Running, S.W., Semerci, A., Cobb, N. (2010): A global overview of drought and heat-induced tree mortality reveals emerging climate change risks for forests. - Forest Ecol. and Man. 259: 660 - 684.

[2] Berberoglu, S., Hickler, T. (2014): Final report on Climate change and environmental risk analysis of turkey. Intensified Cooperation (IntenC): Promotion of German (BMBF)Scientific and Technical Research Council of Turkey (TÜBİTAK) Project no:110Y338.

[3] Breugel, P., Friis, I., Demissew, S., Lilleso, J. P. B., Kindt, R. (2016): Current and future fire regimes and their influence on natural vegetation in Ethiopia. - Ecosystems 19: 369 386.

[4] Cilek, A., Berberoglu, S., Kirkby, M., Irvine, B., Donmez, C., Erdogan, M. A. (2015): Erosion modelling in a Mediterranean sub-catchment under climate change scenarios using Pan-European Soil Erosion Risk Assessment (PESERA). - Int. Arc. Photo. Rem. Sens. Spa. Inf. Sci. XL-7/W3, 359- 365.

[5] Davis, P.H. (1965): Flora of Turkey and the East Aegean islands, Vols. 1 - 9. Edinburgh: Edinburgh University Press.

[6] Deeming, J. E., Burgan, R. E., Cohen, J. D. (1977): The 1978 national fire-danger rating system technical documentation. USDA Forest service Intermountain Forest and Range Experiment Station Ogden, Utah General Technical Report, INT-169, Ogden.

[7] De Groot, W. J., Wardati, Wang, Y. (2005): Calibrating the Fine Fuel Moisture Code for grass ignition potential in Sumatra, Indonesia. - Int. J. Wildland Fire 14: 161-168.

[8] Dudfield, M. (2004): Art and science of forest and rural fire management. - Proceedings AFAC/Bushfire CRC Annual Conference, Perth, October 2004. pp. 183-185.

[9] Dickson, B. G., Prather, J. W., Xu, Y., Hampton, H. M., Aumack, E. N., Sisk, T. D. (2006): Mapping the probability of large fire occurrence in northern Arizona, USA. Landscape Ecol. 21: 747-761.

[10] Demir, Ö., Atay, H., Eskicioglu, O., Tuvan, A., Demircan, M., Akcakaya, A. (2013): Temperature and precipitation projections according to RCP4.5 scenario in Turkey. $-3^{\text {rd }}$ Turkey climate change congress, TİKDEK. http://www.mgm.gov.tr/FILES /iklim/rcp45.pdf. Accessed 10 March 2016.

[11] Dios, V. R., Fischer, C., Colinas, C. (2007): Climate change effects on Mediterranean forests and preventive measures. - New Forests 33: $29-40$. 
[12] Fan, M., Shibata, H., Wang, O. (2016): Optimal conservation planning of multiple hydrological ecosystem services under land use and climate changes in Teshio river watershed, northernmost of Japan. - Ecol. Indic. 62: 1 - 13.

[13] Gabban, A., San-Miguel-Ayanz, J., Viegas, D. X. (2008): A comparative analysis of the use of NOAA-AVHRR NDVI and FWI data for forest fire risk assessment. - Int. J. Remote Sensing 29: 5677-5687.

[14] Hasson, A. E. A., Mills, G. A., Timbal, B., Walsh, K. (2008): Assessing the impact of climate change on extreme fire weather in Southeast Australia. CAWCR Technical Report No. 007. http://www.cawcr.gov.au/technical-reports/CTR_007.pdf. Accessed 20 April 2016.

[15] Hijmans, R. J., Cameron, S. E., Parra, J. L., Jones, P. G., Jarvis, A. (2005): Very high resolution interpolated climate surfaces for global land areas. - Int. J. of Clim. 25: 1965 1978.

[16] Hutchinson, M. F. (1995): Interpolating mean rainfall using thin plate smoothing splines. - Int. J. GIS. 9: 385 - 403.

[17] Hutchinson, M. F. (2004): Anusplin Version 4.3. Centre for Resource and Environmental Studies. The Australian National University, Canberra, Australia.

[18] Jarvis, C. H., Stuart, N. (2001): A comparison among strategies for interpolating maximum and minimum daily air temperatures. Part II: the interaction between the number of guiding variables and the type of interpolation method. - J. of Appl. Meteorology 40: 1075-1084.

[19] Jeffrey, S. J., Carter, J. O., Moodie, K. B., Bestwick, A. R. (2001): Using spatial interpolation to construct a comprehensive archive of Australia climate data. - Environ. Mod. \& Soft. 16: 309 - 330.

[20] Johnson, G. L., Daly, C., Taylor, G. H., Hanson, C. L. (1999): Spatial variability and interpolation of stochastic weather simulation model parameters. - J. of Appl. Meteorology 39: $778-796$.

[21] JRC. (2014): Forest fires in Europe, Middle East and North Africa 2013, joint research centre scientific and technical reports, report No. 10. Publication office of the European Union, Luxemburg.

[22] Schneider, P., Roberts, D.A., Kyriakidis, P. C. (2008): A VARI-based relative greenness from MODIS data for computing the fire potential index. - Remote Sens. of Env. 112: $1151-1167$.

[23] Liu, Z. H., Chang, Y., He, H. S., Hu, Y. M., Wang, W. J. (2009): Effects of different forest fuel treatments on potential forest fire regines in Great Xing'an Mountains: a simulation study. - Chinese J. of Ecol. 28(8): 1462-1469.

[24] Liu, Y., Goodrick, S. L., Stanturf, J. A. (2013): Future US wildfire potential trends projected using a dynamically downscaled climate change scenario. - Forest Ecol. And Man. 294: 120 - 135.

[25] Maffei, C., Leone, A. P., Vella, M., Meoli, G., Tosca, M., Menenti, M. (2007): Retrieval of vegetation moisture indicators for dynamic fire risk assessment with simulated MODIS radiance. - Geoscience and Remote Sensing Symposium, IGARSS 2007. IEEE International. DOI: 10.1109/IGARSS.2007.4423894.

[26] McArthur, A. G., Forestry, A., Bureau, T. (1967): Fire behaviour in eucalypt forests. Canberra: Forestry and Timber Bureau.

[27] Moriondo, M., Good, P., Durao, R., Bindi, M., Giannakopoulos, C., Corte-Real, J. (2006): Potential impact of climate change on fire risk in the Mediterranean area. Climate Res. 31: 85 - 95.

[28] New, M., Hulme, M., Jones, P. (1999): Representing twentieth-century space-time climate varibility. Part I: Development of a 1961-90 mean monthly terrestial climatology. - Journal of Clim. 12: 829-856.

[29] Niculin, G., Kjellström, E., Hansson, U., Strandberg, G., Ullerstig, A. (2011): Evaluation and future projections of temperature, precipitation and wind extremes over Europe in an 
ensemble of regional climate simulations. - Tellus. 63A, $41-55$. DOI: 10.1111/j.16000870.2010.00466.x.

[30] Ozturk, M., Gunel, S., Kucuk, M., Sakcal1, S. (2010): Forest diversity, climate change and forest fires in the Mediterranean region of Turkey. - J. of Env. Bio. 31: 1 - 9.

[31] Rockel, B., Woth, K. (2007): Extremes of near surface wind speed over Europe and their future changes as estimated from an ensemble of RCM simulations. - Clim. Change. 81: 267-280.

[32] Satir, O., Berberoglu, S., Donmez, C. (2016): Mapping regional forest fire probability using artificial neural network model in a Mediterranean forest ecosystem. - Geomatics, Nat. Haz. and Risk. 7(5): 1645-1658.

[33] Sharples, J.J., McRae, R. H. D., Weber, R. O., Gill, A. M. (2009a): A simple index for assessing fire danger rating. - Environ. Model. Soft. 24: $764-774$.

[34] Sharples, J. J., McRae, R. H. D., Weber, R. O., Gill, A. M. (2009b): A simple index for assessing fuel moisture content. - Environ. Model. Soft. 24: 637 - 646.

[35] Stocks, B. J., Lawson, B. D., Alexander, M. E., Vanwagner, C. E., McAlpine, R. S., Lynham, T. J., Dube, D. E. (1989): The Canadian forest fire danger rating system - An overview. - Forestry Chronicle 65: 450-457.

[36] TEMA. (2014): The Turkish Foundation for Combating Soil Erosion, for Reforestration and the protection of Natural Habitats, short report on deforestation of Turkey. http://www.tema.org.tr. Accessed 02 January 2016.

[37] TMSS. (2015): Turkish meteorological state service, long term monthly climate database of Turkey.

[38] TSI. (2016): Turkish Statistical Institute, Address based population registration system. http://www.turkstat.gov.tr/PreTablo.do?alt_id=1059, Accessed 02 Feb. 2016.

[39] Viegas, D. X., Bovio, G., Ferreira, A., Nosenzo, A., Sol, B. (1999): Comparative study of various methods of fire danger evaluation in southern Europe. - Int. J. Wildland Fire 9: 235-246.

[40] WGCD. (2015): WorldClim Global Climate Database, http://www.worldclim.org/. Accessed 11 Jan. 2016.

[41] Ertuğrul, M., Varol, M. (2016): Evaluation of fire activity in some regions of Aegean Coasts of Turkey via Canadian Forest Fire Weather Index System (CFFWIS). - Appl. Ecol. and Env. Res. 14(2): 93 - 105. 


\section{APPENDIX}

Appendix 1. Forest fire probability difference on basin scale

\begin{tabular}{|l|r|r|r|r|}
\hline Basin name & $\begin{array}{c}\text { Current mean } \\
\text { F index value }\end{array}$ & $\begin{array}{c}\text { Future mean } \\
\text { F index value }\end{array}$ & $\begin{array}{c}\text { F index } \\
\text { difference* }\end{array}$ & $\begin{array}{c}\text { Percent } \\
\text { difference }\end{array}$ \\
\hline Gediz & 0.195 & 0.215 & 0.02 & $10.26 \%$ \\
\hline Marmara & 0.257 & 0.304 & 0.047 & $18.29 \%$ \\
\hline Small Menderes & 0.271 & 0.306 & 0.035 & $12.92 \%$ \\
\hline Big Menderes & 0.183 & 0.205 & 0.022 & $12.02 \%$ \\
\hline East Mediterranean & 0.161 & 0.209 & 0.048 & $29.81 \%$ \\
\hline Middle Mediterranean & 0.231 & 0.275 & 0.044 & $19.05 \%$ \\
\hline West Mediterranean & 0.258 & 0.313 & 0.055 & $21.32 \%$ \\
\hline Aegean & 0.308 & 0.353 & 0.045 & $14.61 \%$ \\
\hline Susurluk & 0.252 & 0.295 & 0.043 & $17.06 \%$ \\
\hline Yesilirmak & 0.19 & 0.229 & 0.039 & $20.53 \%$ \\
\hline Coruh & 0.144 & 0.182 & 0.038 & $26.39 \%$ \\
\hline Aras & 0.093 & 0.115 & 0.022 & $23.66 \%$ \\
\hline Euprates & 0.05 & 0.063 & 0.013 & $26.00 \%$ \\
\hline Tigris & 0.05 & 0.071 & 0.021 & $42.00 \%$ \\
\hline Lake Van & 0.02 & 0.032 & 0.012 & $60.00 \%$ \\
\hline East Black Sea & 0.237 & 0.309 & 0.072 & $30.38 \%$ \\
\hline West Black Sea & 0.264 & 0.322 & 0.058 & $21.97 \%$ \\
\hline Seyhan & 0.12 & 0.161 & 0.041 & $34.17 \%$ \\
\hline Ceyhan & 0.128 & 0.173 & 0.045 & $35.16 \%$ \\
\hline Hatay & 0.182 & 0.256 & 0.074 & $40.66 \%$ \\
\hline Lake Burdur & 0.121 & 0.139 & 0.018 & $14.88 \%$ \\
\hline Central Anatolia & 0.039 & 0.046 & 0.007 & $17.95 \%$ \\
\hline Meric & 0.107 & 0.124 & 0.017 & $15.89 \%$ \\
\hline Afyon & 0.062 & 0.071 & 0.009 & $14.52 \%$ \\
\hline Sakarya & 0.12 & 0.14 & 0.02 & $16.67 \%$ \\
\hline Kizilirmak & 0.109 & 0.128 & 0.019 & $17.43 \%$ \\
\hline
\end{tabular}

*Future mean $\mathrm{F}$ index value - Current mean $\mathrm{F}$ index value 